\title{
The level of pedagogical formation students' academic locus of control
}

\author{
Süleyman Can', Erdil Durukan² \\ ${ }^{1}$ Department of Primary Education, Muğla Sitk1 Koçman University, Turkey \\ ${ }^{2}$ School of Physical Educational and Sport, Balıkesir University, Turkey
}

\begin{tabular}{l} 
Article Info \\
\hline Article history: \\
Received Feb 8, 2019 \\
Revised Jul 28, 2019 \\
Accepted Aug 25, 2019 \\
\hline
\end{tabular}

Keywords:

Academic locus of control Pedagogical formation Student

\begin{abstract}
Academic locus of control has an important place in explaining students' behaviors in educational settings. The purpose of the current study is to determine the level of the pedagogical formation students' academic locus of control and to investigate whether this level varies depending on some variables. The study employed the survey model, one of the quantitative research methods. The universe of the study is comprised of the students enrolled at the pedagogical formation program initiated in the fall term of 2015-2016 academic year in Muğla Sitk1 Koçman University and the sampling consists of 397 pedagogical formation students. As the data collection tool, the academic locus of control scale was used in the current study. It was concluded that the pedagogical formation students' level of academic locus of control is medium. It was also found that the students' academic locus of control, internal locus of control and external locus of control do not vary significantly depending on gender and department; yet, vary significantly depending on age. Furthermore, the pedagogical formation students' level of satisfaction was found to be significantly correlated with the external locus of control but not with the internal locus of control and academic locus of control.
\end{abstract}

Copyright $@ 2019$ Institute of Advanced Engineering and Science. All rights reserved.

\section{Corresponding Author:}

Süleyman Can,

Department of Elementary Education,

Mugla Sitk1 Kocman University,

Kotekli, Mugla County 48000, Turkey.

Email: scan@mu.edu.tr

\section{INTRODUCTION}

The basic conditions of creating effective learning environments within the educational and instructional process include determining the individual differences of students. Individual differences affect the success and course-oriented motivation of individuals during educational and instructional activities. Constructs such as intelligences, abilities, self-confidence, motivation, learning and thinking styles possessed by individuals lead to emergence of individual differences. The construct of locus of control is also conducive to the formation of individual differences.

Locus of control based on Rotter's social learning theory depends on the degree to which individuals perceive their personal responsibility for events [1]. Locus of control is made up of two dimensions being internal locus of control and external locus of control. The individuals having external locus of control believe that external forces (luck, destiny or others' behaviors) are the main determinants and thus they believe that they can change very little with their abilities and behaviors; therefore, they do invest either no or very little effort [2]. The individuals with internal locus of control are of the opinion that that what is important is their own behaviors [3] and thus, they put forth the effort needed [4]. The individuals with external locus of control are claimed to be less eager to demonstrate their abilities, to experience the feeling of helplessness more and to have lower expectation of success [5]. The individuals with internal locus of 
control on the other hand have been claimed to be more successful in coping with stress [6], to be more active in interpersonal relationships and to be more likely to fulfill their responsibilities [7], to be more successful in solving problems [8], [9], to be more effective in making decisions [10], to have higher selfefficacy [11], to be academically more successful [12, 13] and to be socially more active [14].

In the academic setting, locus of control corresponds to the evaluation of students' individual success and failures at school [12]. The academic locus of control offers insights about an individual's generalized expectations in an academic environment.

Academic external locus of control refers to students' belief that the positive or negative outcomes or successes or failures they have attained at school have been brought about by factors other than their own control, such as chance, difficulty of the task or the behavior of other individuals. Academic internal locus of control on the other hand refers to students' belief that any academic success or failure is due to their own behaviors or personality traits [15]. The existence of internal and external academic locus of control in an academic environment is influential on carrying out assignments, duties and responsibilities, academic achievement, decision making skills and career selection [16]. Given the delineations above, it can be said that locus of control has an important place in explaining students' behaviors in educational environments. Thus, it seems to be important to determine pre-service teachers' internal and external locus of control together making up academic locus of control. It is also believed to be important to determine the factors affecting their locus of control. In this regard, the purpose of the current study was set to be to determine pedagogical formation students' level of academic locus of control and to reveal the relationships between their academic locus of control and some variables.

\section{RESEARCH METHOD}

The current study is a qualitative study employing the survey model. The survey model refers to an investigation made on a group taken from a universe made up of many elements to reach a general conclusion on the universe [17].

The universe of the current study is made up of the pedagogical formation students enrolled in Muğla Sitkı Koçman University in 2015-2016 academic year. The sampling of the study is comprised of 397 students randomly selected from among the universe as shown in Table 1.

\begin{tabular}{|c|c|c|c|}
\hline & Jariables & $\mathrm{N}$ & $\%$ \\
\hline \multirow{4}{*}{ Age } & 20 and under & 111 & 28 \\
\hline & $21-25$ & 119 & 30 \\
\hline & $26-30$ & 61 & 15.4 \\
\hline & 31 and over & 106 & 26.7 \\
\hline \multirow{2}{*}{ Gender } & Female & 222 & 55.9 \\
\hline & Male & 175 & 44.1 \\
\hline
\end{tabular}

Of the 397 pedagogical formation students participating in the current study, 28\% (111) are in the age group "20 and under", $30 \%$ (119) are in the age group " $21-25$ ", 15.4\% (61) are in the age group "26-30" and $26,4 \%$ (106) are in the age group " 31 and over". Of the 397 pedagogical formation students participating in the current study, $55.9 \%$ (222) are females and $44.1 \%$ (175) are males.

As the data collection tool in the current study, the academic locus of control scale and a personal information form were used. The academic locus of control scale was developed by [2]. The academic locus of control scale is comprised of 17 items and two dimensions being internal locus of control and external locus of control. Of these 17 items, 11 are related to external locus of control and 6 are related to internal locus of control. The internal consistency coefficient for the internal locus of control dimension was found to be .78 and the internal consistency coefficient for the external locus of control was found to be .79 . The academic locus of control scale does not have any reverse items. The scores taken from the internal locus of control and external locus of control dimensions can be interpreted as follows: the higher the mean score taken from one dimension, the more characteristics of the related dimension the respondent has.

In the analysis of the collected data, first the collected data were entered into the computer environment; the questionnaires not having been responded properly were excluded from the analyses. The data were analyzed in IBM SPSS 21 program package. The homogeneity of the variance was examined; as a result of the homogeneity tests, the students' level of academic locus of control was determined. The correlation between the academic locus of control and the gender variable was tested with t-test and the correlations between the level of academic locus of control and the age, department and satisfaction were tested with one-way variance analysis (ANOVA). 


\section{RESULTS AND DISCUSSION}

In line with the general purpose of the study, the results of the analyses conducted to find answers to the research questions are presented in this section. Findings related to the pedagogical formation students' level of academic locus of control are given in Table 2. As can be seen in Table 2, the pedagogical formation students' mean level of academic locus of control was found to be medium. The mean level of internal locus of control was found to be high and the mean level of external locus of control was found to be low.

Table 2. Pedagogical formation students' levels of academic locus of control

\begin{tabular}{cccccc}
\hline & $\mathrm{N}$ & $\overline{\mathrm{X}}$ & $\mathrm{Ss}$ & Min. & Max. \\
\hline External control & 397 & 1.44 & .55 & 1.00 & 3.00 \\
Internal control & 397 & 2.69 & .54 & 1.00 & 3.00 \\
Academic control & 397 & 1.95 & .38 & 1.00 & 3.00 \\
\hline
\end{tabular}

In Table 3, the results of t-test conducted to determine whether the pedagogical formation students' level of academic locus of control varies significantly depending on the gender variable are presented. As can be seen in Table 3, the pedagogical formation students' levels of academic locus of control do not vary significantly depending on the gender variable $(p>.05)$. In other words, gender was found to have not a significant influence on academic locus of control, internal locus of control and external locus of control. When the relevant literature is reviewed, it is seen that there are some studies reporting that pre-service teachers' academic locus of control does not vary by gender [18-23].

Table 3. Gender-based differences between the pedagogical formation students' levels of academic locus of control

\begin{tabular}{ccccccc}
\hline & Gender & $\mathrm{N}$ & $\overline{\mathrm{X}}$ & $\mathrm{Ss}$ & $\mathrm{t}$ & $\mathrm{p}$ \\
\hline Academic control & Female & 222 & 2.85 & .44 & 1.29 & .196 \\
& Male & 175 & 2.91 & .49 & & \\
Internal control & Female & 222 & 4.05 & .71 & 1.95 & .846 \\
& Male & 175 & 4.07 & .77 & & \\
External control & Female & 222 & 2.19 & .65 & 1.25 & .210 \\
& Male & 175 & 2.28 & .71 & & \\
\hline
\end{tabular}

In Table 4, the results of the one-way variance analysis (ANOVA) conducted to determine whether the pedagogical formation students' levels of academic locus of control vary significantly depending on the age variable are given.

As can be seen in Table 4, the pedagogical formation students' levels of academic locus of control, internal locus of control and external locus of control vary significantly by age. The significant difference found in the external locus of control dimension seems to have stemmed from the difference between the age groups 21-25 and 31 and over. The significant difference found in the internal locus of control dimension seems to have stemmed from the difference between the age groups 20 and under and 26-30. The significant difference found in the academic locus of control dimension seems to have stemmed from the difference between the age groups 21-25 and 31 and over. This finding is parallel to [24] reporting that with increasing age, individuals tend to be more internally controlled.

Table 4. The results of one-way variance analysis conducted to determine whether the pedagogical formation students' levels of academic locus of control vary significantly depending on the age variable

\begin{tabular}{|c|c|c|c|c|c|c|c|}
\hline & & $\begin{array}{l}\text { Sum of } \\
\text { Squares }\end{array}$ & $\mathrm{Sd}$ & $\begin{array}{l}\text { Mean } \\
\text { Squares }\end{array}$ & $\mathrm{F}$ & $\mathrm{p}$ & Difference \\
\hline External & Between-groups & 5.15 & 3 & 1.72 & 3.77 & .01 & $2-4$ \\
\hline \multirow[t]{2}{*}{ Control } & Within-groups & 179.21 & 393 & .46 & & & \\
\hline & Total & 184.36 & 396 & & & & \\
\hline Internal & Between-groups & 5.10 & 3 & 1.70 & 5.16 & .03 & $1-3$ \\
\hline \multirow[t]{2}{*}{ Control } & Within-groups & 211.90 & 393 & .54 & & & \\
\hline & Total & 217.00 & 396 & & & & \\
\hline Academic & Between-groups & 1.89 & 3 & .63 & 2.91 & .03 & $2-4$ \\
\hline \multirow[t]{2}{*}{ Control } & Within-groups & 84.87 & 393 & .22 & & & \\
\hline & Total & 86.76 & 396 & & & & \\
\hline
\end{tabular}


In Table 5, the results of the one-way variance analysis (ANOVA) conducted to determine whether the pedagogical formation students' levels of academic locus of control vary significantly depending on the department variable are given. As can be seen in Table 5, the pedagogical formation students' levels of academic locus of control, internal locus of control and external locus of control do not vary significantly depending on the department variable. Whether the students are from literacy departments, numeracy departments or vocational departments does not lead to any significant influence on any of the dimensions of academic locus of control. In a study conducted by [25] on senior students of all the departments of the KTÜ Education Faculty, it was found that the students' academic locus of control does not vary significantly depending on the department attended. Similarly, [26], [27] reported that the students' academic locus of control does not vary significantly depending on the department variable.

Table 5. The results of one-way variance analysis conducted to determine whether the pedagogical formation students' levels of academic locus of control vary significantly depending on the department variable

\begin{tabular}{llllllll}
\hline & & $\begin{array}{l}\text { Sum of } \\
\text { Squares }\end{array}$ & Sd & $\begin{array}{l}\text { Mean } \\
\text { Squares }\end{array}$ & F & p & Difference \\
\hline External & Between-groups & .18 & 2 & .09 & .19 & .83 & - \\
Control & Within-groups & 184.18 & 394 & .47 & & & \\
& Total & 184.36 & 396 & & \multirow{2}{*}{.53} & .59 & - \\
Internal & Between-groups & .58 & 2 & .29 & & & - \\
Control & Within-groups & 216.42 & 394 & .55 & & & .03 \\
& Total & 217.00 & 396 & & .98 & - \\
Academic & Between-groups & .01 & 2 & .01 & & & \\
Control & Within-groups & 86.75 & 394 & .22 & & & \\
& Total & 86.76 & 396 & & & \\
\hline
\end{tabular}

In Table 6, the results of the one-way variance analysis (ANOVA) conducted to determine whether the pedagogical formation students' levels of academic locus of control vary significantly depending on the satisfaction variable are given. As can be seen in Table 6, the pedagogical formation students' level of external locus of control varies significantly depending on the satisfaction variable but their levels of academic locus of control and external locus of control do not. When the source of this difference was examined, it was found that it stemmed from the difference between those who are satisfied and those who are dissatisfied and between those who are partially satisfied and those who are dissatisfied.

Table 6. The results of one-way variance analysis conducted to determine whether the pedagogical formation students' levels of academic locus of control vary significantly depending on the satisfaction variable

\begin{tabular}{|c|c|c|c|c|c|c|c|}
\hline & & $\begin{array}{l}\text { Sum of } \\
\text { Squares }\end{array}$ & $\mathrm{Sd}$ & $\begin{array}{c}\text { Mean } \\
\text { Squares }\end{array}$ & $\mathrm{F}$ & $\mathrm{p}$ & Difference \\
\hline \multirow[t]{3}{*}{ External Control } & Between-groups & 3.65 & 2 & 1.83 & 3.98 & .02 & $1-2$, \\
\hline & Within-groups & 180.71 & 394 & .46 & & & $2-3$ \\
\hline & Total & 184.36 & 396 & & & & \\
\hline \multirow[t]{3}{*}{ Internal Control } & Between-groups & .53 & 2 & .27 & .48 & .62 & - \\
\hline & Within-groups & 216.47 & 394 & .55 & & & \\
\hline & Total & 217.00 & 396 & & & & \\
\hline \multirow[t]{3}{*}{ Academic Control } & Between-groups & 1.23 & 2 & .61 & 2.83 & .06 & - \\
\hline & Within-groups & 85.53 & 394 & .22 & & & \\
\hline & Total & 86.76 & 396 & & & & \\
\hline
\end{tabular}

\section{CONCLUSION}

In the current study, it was found that the pedagogical formation students' level of academic locus of control is medium, level of internal locus of control is high and level of external locus of control is low. The students' high level of internal locus of control can be evaluated as a positive finding in terms of the students' qualifications. The students with internal locus of control admit that their success depends on their own behaviors and thus they invest the required effort. They are more successful in coping with stress, more active in interpersonal relationships, take their responsibility, their motivation is high, they are more successful in solving problems, their self-efficacy is high, they are academically successful and socially active. Whether individuals are internally or externally controlled in their academic endeavors is highly influential on making preferences that will shape the future such as fulfilling duties and responsibilities and making academic decisions. In addition to these findings it was also found that the pedagogical formation 
students' levels of academic locus of control, internal locus of control and external locus of control do not vary significantly depending on the department and gender variables. However, their levels of academic locus of control, internal locus of control and external locus of control vary significantly by age. Besides, their level of external locus of control varies significantly depending on the satisfaction variable but their levels of academic locus of control and external locus of control do not.

The current study was conducted with the pre-service teachers enrolled in a pedagogical formation program. Similar studies can be conducted on pre-service teachers from different departments. In the current study, four independent variables (gender, age, department, satisfaction level) thought to affect academic locus of control were investigated. Future research may explore the effect of different variables on academic locus of control. Whether individuals are internally or externally controlled has significant impacts on their academic experiences. Future research can focus on ways of developing students' academic locus of control.

\section{REFERENCES}

[1] JB. Rotter, "Social learning and clinical psychology," Prentice-Hall. New York. 1954.

[2] İ. Dağ, "Kontrol Odağı Ölçeği (KOÖ): Ölçek geliştirme, güvenirlik ve geçerlik çalışması," Türk Psikoloji Dergisi, vol. 17, pp. 77-90, 2002.

[3] E. Akbulut, "Müzik eğitimi anabilim dalı öğrencilerinin denetim odaklarına ilişkin algıları," Gazi Eğitim Fakültesi Dergisi, vol. 26(3), pp. 171-180, 2006.

[4] Yeşilyaprak B. "Denetim odağı" in Yıldız Kuzgun, Deniz Deryakulu (Edt.), "Eğitimde bireysel farklılıklar," Nobel Yayın Dağıtım. Ankara. 2004.

[5] GM. Davies, YM. Binik, P. Gorman, M. Dattell, B. McCloskey, G. Oscar and et al, "Perceived self-efficac you come expectancies and negative mood states in and stagerena ldisease," Journal of Abnormal Psychology, vol. 91(4), pp. 241-244, 1982.

[6] C. Arslan, B. Dilmaç and E. Hamarta, "Coping with stress and traitanxiety in terms of locus of control: A Study with Turkish University Students," Social Behaviour and Personality, vol. 37(6), pp. 791-800. 2009.

[7] M. Altın and N. Karanc1, "How does locus of control and in flated sense of responsibility relatet oobsessivecompulsive symptoms in Turkish a dolescents?," Journal of Anxiety Disorders, vol. 22, pp. 1303-1315, 2008.

[8] N. Konan, "Relationship between locus of controland problem-solving skills of high school administrators," International Journal of Social Sciences and Education, vol. 3(3), pp. 786-794, 2013.

[9] NB. Serin and R. Derin, "İlköğretim öğrencilerinin kişilerarası problem çözme becerisi algıları ve denetim odağı düzeylerini etkileyen faktörler," Uluslararası Insan Bilimleri Dergisi, vol. 5(1), pp. 1-18, 2008.

[10] AE. Çoban and Z. Hamamcı, "Kontrol odakları farklı ergenlerin karar stratejileri açısından incelenmesi," Kastamonu Eğitim Dergisi, vol. 14(2), pp. 393-402, 2006.

[11] J. Carifio and L. Rhodes, "Construct validities and the empirical relationships between optimism, hope, selfefficacy, andlocus of control," Work, vol. 19, pp. 125-136, 2002.

[12] ME. Altıparmak, "Akademik kontrol odağı ve başarı hedef yönelimleri: Beden eğitimi öğrencileri üzerinde bir çalışma," Spor ve Performans Araştırmaları Dergisi, vol. 6(2), pp. 73-78, 2015.

[13] Z. Kazak Çetinkalp, "The relationship between academic locus of control and achievement goals among physical education teaching program students," World Applied Sciences Journal, vol. 10(11), pp. 1387-1391, 2010.

[14] A. Anderson, J. Hattie and RJ. Hamilton, "Locus of control, self- efficacy, and motivation in different schools: Is moderation the key to success?," Educational Psychology, vol. 25(5), pp. 517-535, 2005.

[15] A. Akın, "Akademik Kontrol Odağı Ölçeği: Geçerlik ve güvenirlik çalışması," Çukurova Üniversitesi Eğitim Fakültesi Dergisi, vol. 34(3), pp. 9-17, 2007.

[16] H. Sariçam, "Psychometric properties and adaptation of the academic locus of control scaletothe Turkish adolescents," Elementary Education Online, vol. 13(4), pp. 1135-1144, 2014.

[17] N. Karasar, "Bilimsel araştırma yöntemi," Ankara: Nobel Yayın Dağıtım, 2012.

[18] G. Başol and E. Türkoğlu, "Sınıf öğretmeni adaylarının düşünme stilleri ile kontrol odağı durumları arasındaki ilişki," Uluslararası İnsan Bilimleri Dergisi, vol. 6(1), pp. 732-757, 2009.

[19] B. Yalçın, S. Tetik and A. Açıkgöz, "Yüksekokul öğrencilerinin problem çözme becerisi algıları ile control odağı düzeylerinin belirlenmesine yönelik bir araştırma," Organizasyon ve Yönetim Bilimleri Dergisi, vol. 2(2), 2010.

[20] M. Cengil, "Gazi üniversitesi Çorum İlahiyat Fakültesi öğrencilerinin denetim odaklarının çeşitli değişkenlere göre incelenmesi," Gazi üniversitesi Çorum Illahiyat Fakültesi Dergisi, vol. 3(5), pp. 65-88, 2004.

[21] P. Şara, "Sınıf Öğretmeni adaylarının ögrenme ve ders çalışma stratejileri, problem çözme becerileri ve denetim odă̆ düzeylerinin çeşitli değişkenler açısından incelenmesi," (Unpublished Doctoral Thesis), Dokuz Eylül Üniversitesi, Eğitim Bilimler Enstitüsü, İzmir, 2012.

[22] AS. Saracaloğlu, O Serin and n Bozkurt, "Eğitim Bilimleri Enstitüsü lisansüstü öğrencilerinin problem çözme ve denetim odağı düzeylerinin bazı değişkenler açısından incelenmesi," DEÜ Buca Eğitim Fakültesi Dergisi, vol. 1, pp. 237-242, 2005.

[23] U. Durna and FK. Şentürk, "Üniversite öğrencilerinin denetim odakalrını çeşitli değişkenler yardımıyla tespit etmeye yönelik bir çalışma," ZKÜ Sosyal Bilimler Dergisi, vol. 8(15), pp. 37-48, 2012

[24] F. Korkut, "İlkokul öğrencilerinin kendilerine ve ailelerine ilişkin bazı değişkenlerin denetim odakları üzerinde etkisi," (Yayınlanmamış Bilim Uzmanlığı Tezi). Hacettepe Üniversitesi, Ankara. 1986.

[25] B. Yanılmaz, "Öğretmen adaylarında denetim odağının çeşitli değiş̧kenlere göre incelenmesi," (Unpublished Master Thesis), Karadeniz Teknik Üniversitesi, Sosyal Bilimler Enstitüsü, Trabzon. 1999.

Determination of the level of pedagogical formation students' academic locus of control (Süleyman Can) 
[26] OZ. Yazar, "Kendini Kabul Düzeyi Düsük ve Yüksek Olan Üniversite Öğrencilerinin Denetim Odağı Algılamaları İle Kendini Ayarlama Becerileri Arasındaki İlişki," (Unpublished Master Thesis), On Dokuz Mayıs Üniversitesi, Sosyal Bilimler Enstitüsü, Samsun, 1996.

[27] AS. Saracaloğlu, N. Yenice and B. Özden, "Fen Bilgisi, Sosyal Bilgiler ve Sınıf Öğretmeni Adaylarının Öğretmen Öz-yeterlik Algılarının ve Akademik Kontrol Odaklarının İncelenmesi," Pamukkale Üniversitesi Eğitim Fakültesi Dergisi, vol. 34, pp. 227-250, 2013.

\section{BIOGRAPHIES OF AUTHORS}
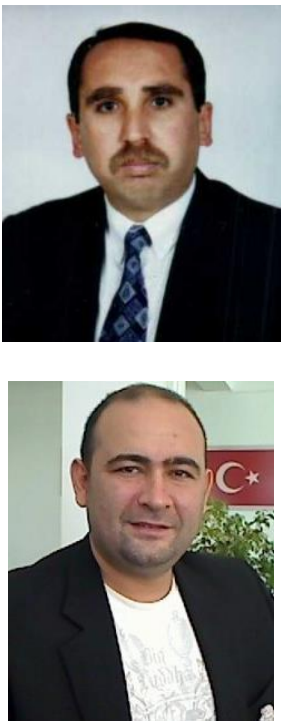

Süleyman Can, PhD Gazi University (Ankara, Turkey), is an associate professor of primary teacher education. His interests are physical education and sports, individual differences in education, and teacher education. He is currently employed at Muğla Sitkı Koçman University, Primary Teacher Education Department, Muğla, Turkey.

Erdil Durukan, PhD Gazi University (Ankara, Turkey), is an assistant professor of coaching education. His interests are physical education and sports, exercise and sports physiology, nutrition in sports. He is currently employed at Balikesir University, School of Physical Education and Sports, Balıkesir, Turkey. 